\title{
Personales kjennskap og holdninger til retningslinjer og prosedyrer for selvmordsrisikovurdering i psykisk helsevern
}

\author{
Av Kim Larsen og Ping Qin
}

\section{SAMMENDRAG}

Artikkelen presenterer resultatene av en spørreskjemaundersøkelse ( $\mathrm{N}=396$ ) om personale i psykisk helseverns rapporterte kjennskap og holdning til rutiner og prosedyrer knyttet til selvmordsrisiko. Deltakerne rapporterer om gjennomgående god kjennskap til formalkrav for selvmordsrisikovurdering, slik som rutiner i egen seksjon, prosedyrer i elektronisk kvalitetshåndbok, gjeldende lovverk og nasjonale retningslinjer. Det er vesentlige forskjeller mellom personale med ulik klinisk bakgrunn, med høyere rapportert kjennskap hos lege/psykiater, og personale som ofte møter suicidale pasienter. Deltakerne ser både fordeler ved prosedyrene (målrettethet/trygghet på å få med seg det som er relevant), men også noen ulemper (tidkrevende/juridisk fokus). Det pågår en debatt i psykisk helsevern om bruken av standardiserte prosedyrer for vurdering av selvmordsrisiko. I den foreliggende undersøkelsen presenteres systematiske data som kan bidra til forståelse om klinikeres kjennskap og holdning til disse rutinene og prosedyrene.

In the present paper we present results of a survey study among mental health care personnel $(\mathrm{N}=396)$ on their knowledge and perception of routines and procedures related to suicide risk assessment. The participants report a generally high level of familiarity with formal requirements for evaluation of suicide risk, such as routines in their own workplace, procedures in the hospital's electronic quality management system, current legislation, and national guidelines. There are also notable differences by clinical background with higher levels of familiarity among doctors/ psychiatrists and staff frequently seeing suicidal patients. The perceived benefits of these formal requirements include clear goal setting and confidence ensuring to do what's relevant, whilst the commonly perceived drawbacks are that these routines and procedures are time-consuming and have an overly legalistic focus. There is an ongoing debate about the use of standardized procedures for evaluating suicide risk in Norway. The present article provides rich insights that contributes to our understanding on clinicians' knowledge about and attitudes toward these routines and procedures.

EVIDENSBASERT PRAKSIS er vår tids dominerende tidsånd i medisin og psykologi (Ekeland, 2009; Grimen \& Terum, 2009; Harrison, 1998). Der en tidligere hadde aksept for klinisk skiønn og en betydelig variasionsbredde i faglig praksis, forutsettes det nå at en begrunner praksis i empiriske studier av hvilken behandling som har dokumentert effekt (på gruppenivå) for en gitt tilstand. Standardiserte prosedyrer er en del av denne tidsånd (Ekeland, 2004; Walshe \& Shelton, 1998). Idealet er at uansett hvilken behandler pasienten møter skal han/hun bli mott på samme måte med en diagnostisk vurdering og tiltak utgått fra forskningsbegrunnede standardiserte prosedyrer, og hvor dette også skal monitoreres og kontrolleres (Flynn, 2002; Walshe \& Shelton, 1998). Møtet med pasienten skal integrere klinikerens relasjonelle sensitivitet og kliniske erfaring med de beste tilgiengelige systematiske forskningsresultater (Sackett et al., 1996). På denne bakgrunn er det utarbeidet et økende antall veiledere og prosedyresamlinger $\mathrm{i}$ psykisk helsevern. Nasionale retningslinjer for forebygging av selvmord i psykisk helsevern (Sosial og helsedirektoratet, 2008) var 
avgiørende for å forankre selvmordsrisikovurderinger innenfor en slik ramme.

Nasionale retningslinjer skiller mellom kartlegging og vurdering av selvmordsrisiko. Kartlegging er en innledende «screening» og skal utføres av alle kliniske personalgrupper og har til hensikt å avdekke om det kan foreligge selvmordsrisiko eller ikke. Dette kan giøres ved å stille pasienten direkte spørsmål om aktuell suicidalitet og tidligere selvmordsadferd (selvmordstanker, selvmordsplaner, tidligere selvmordsforsøk). Finner en grunn til bekymring skal det utføres en full selvmordsrisikovurdering. Dette er en mer omfattende prosess, og skal utføres av leger, psykologer eller annet særskilt kvalifisert personale. En skal her vurdere grad av risiko opp mot kjente risikofaktorer på gruppenivå i kombinasjon med pasientens kliniske tilstand, vurdere om risikoen er av en slik art at en bør sette i gang tiltak, samt vurdere tiltakenes mulige negative terapeutiske effekt. En totalvurdering av dette skal munne ut i en begrunnet konklusion (se Herrestad \& Larsen, 2012 for en mer nyansert fremstilling av denne prosessen). For enkelhets skyld har vi i denne artikkelen valgt å benevne rutiner og prosedyrer for både kartlegging og vurdering av selvmordsrisiko med et samlebegrep: formalkrav for vurdering av selvmordsrisiko.

Det er en kontinuerlig debatt om hvordan den overliggende tidsånd kan påvirke praksis i psykisk hel-

severn generelt, samt hvordan prosedyrene spesielt kan innskrenke klinisk autonomi på en måte som kan være uheldig og begrensende (Chunduri et al., 2017; Hagen et al., 2018; Smith et al., 2015). Det er imidlertid få systematiske studier hvor en har undersøkt klinikeres kjennskap og hold-

\section{Det er imidlertid få} systematiske studier hvor en har undersøkt klinikeres kjennskap og holdninger til prosedyrene. ninger til prosedyrene. De fleste studier er interviustudier (se for eksempel Chundury et al., 2017; Godin et al., 2004; Muir-Cochrane et al., 2011 og Waern et al., 2016), med kun ett unntak (Wand et al., 2015). Selv om det er flere kvinner enn menn som arbeider i psykisk helsevern har vi ikke kjennskap til at det foreligger noen studier hvor en har undersøkt om det er kjønnsforskjeller i kjennskap og holdninger til prosedyrene.

Når en ser på situasjonen i Norge, utforte Per Erik Sørum (2012) en kvalitativ undersøkelse av hvordan prosedyrene i nasjonale retningslinjer ble praktisert i akutt-team, og fant en betydelig variasjon i praksis i ulike team. Hagen et al. (2017) utførte en interviustudie av åtte psykoterapeuter og åtte psykiatriske sykepleiere, og fant en konflikt mellom risikovurdering og kontroll 
(«duty and control») på den ene siden og relasjonen og omsorgen («connection and care») til pasienten på den andre siden (se også Hagen, 2018). Østlie (2018) utførte en prosessuell studie av psykoterapeutiske forløp hvor suicidalitet var sentralt, og fant noe av det samme dilemmaet mellom risikovurderinger og kontroll på den ene siden og den terapeutiske relasionen til pasienten på den andre. Myhre (2016) utførte en Questback-basert undersøkelse av personalets opplevelse av rutiner og prosedyrer for vurdering av selvmordsrisiko ved Sykehuset Vestfold, og fant at kunnskapen om formalkrav knyttet til vurdering av selvmordsrisiko giennomgående var høy. Respondentene oppfattet formalkravene som meningsfulle i seg selv, men var frustrert over papirarbeidet og tidsbruken prosedyrene krevde, og at dette gikk på bekostning av pasientkontakten.

For å få mer innsikt i helsepersonales kiennskap og holdninger til retningslinjer og prosedyrer for selvmordsrisikovurdering, har vi giennomfort en stor undersøkelse med data fra medarbeidere i Klinikk for psykisk helsevern og rusbehandling ved Sykehuset Østfold. Vi ønsket for det første å undersøke i hvilken grad personalet hadde kjennskap til gieldende lover (hvor det sentrale er forsvarlighetskravet i Helsepersonelloven og Spesialisthelsetjenesteloven, henholdsvis paragraf 4 og 2-2), nasionale retningslinjer, prosedyrer i elektronisk kvalitetshåndbok (EK), samt rutiner i egen seksjon. Dernest onsket vi å kartlegge personalets oppfatninger og holdninger til prosedyrer og rutiner for vurdering av selvmordsrisiko. Vi ville også undersøke om det er noen kjønnsmessige forskjeller i kjennskap og holdninger, da det er flere kvinner enn menn som jobber på psykisk helsevern. Til slutt ville vi undersøke om det var noen sammenheng mellom personalets faglige bakgrunn og deres rapporterte kjennskap til og holdninger til prosedyrene, og diskutere hvilke implikasjoner eventuelle forskjeller vil kunne ha for psykisk helsevern.

\section{Metode}

\section{Deltagere og prosedyre}

Undersøkelsen ble utført online i Klinikk for psykisk helsevern og rusbehandling ved Sykehuset Østfold, som dekker Ostfold fylke med en befolkning på ca. 300 o०० mennesker. Dette inkluderer døgnavdelinger for både barn/ungdom og voksne, poliklinikker, ambulante team og Assertive community treatment (ACT).

Invitasjon til å delta i spørreskjemaundersøkelsen ble sendt pr. e-mail til samtlige ansatte i Klinikk for psykisk helsevern og rusbehandling 8. mai 2016. Svarfristen ble satt til 5. juni. Det ble sendt en purring 29. mai til de som ikke hadde svart. Undersøkelsen ble sendt ut til totalt 1385 personer, hvorav 503 responderte, noe som utgiør en responsrate på 36,3\%. På det innledende spørsmålet «Ligger det til dine arbeidsoppgaver å spørre om og journalføre pasienters selvmordstanker og/eller planer?» svarte 396 personer bekreftende, noe som var «inngangsbilletten» til undersøkelsen. Prosedyrene er slik at de som har ansvar for å spørre om pasienten har selvmordstanker og/eller planer også har automatisk ansvar for å dokumentere resultatet.

\section{Kartlagte variabler}

Yrkesbakgrunn: Respondentene ble innledningsvis spurt om hvor ofte de møtte selvmordsnære pasienter og ble bedt om å besvare dette på en fem-leddet skala fra «nesten daglig» til «svært sjeldent». Her benyttet vi begrepet selvmordsnær i stedet for suicidal for å lette sammenligning av våre data med en lignende undersøkelse (Myhre, 2016).

Deretter ble personalets kjennskap målt, også på en fempunkts Likert-skala - til gieldende lover, nasjonale retningslinjer, prosedyrer i EK og rutiner i egen seksjon knyttet til selvmordsproblematikk - dvs. formalkrav for vurdering av selvmordsrisiko.

Personalets oppfatning og holdninger til prosedyrene ble målt ved at de skulle ta stilling til seks spørsmål om prosedyrene. Det ble benyttet en fempunkts Likert-skala med et nøytralt midtpunkt (hverken enig eller uenig) og to grader av enighet/uenighet hvor 1 er helt enig, 2 delvis enig, 4 delvis uenig og 5 helt uenig.

Etter kartlegging av oppfatninger og holdninger ble respondentene spurt om de selv hadde mistet pasienter i selvmord. De siste spørsmålene i undersøkelsen omfattet spørsmål om respondentens kjønn, yrkestittel, arbeidsplass, og antall års praksis på denne arbeidsplassen. Disse spørsmålene er plassert sist slik at en ikke skal få «framing effects» av dem (se for eksempel Tversky \& Kahneman, 1981); de skal ikke påvirke respondentene til å svare på en måte som setter dem i et mest mulig gunstig lys. Undersøkelsen ble avsluttet med en mulighet for respondentene til å gi kommentarer til undersøkelsen i fritekst.

\section{Statistikk}

Vi giennomførte deskriptive analyser og utforsket videre sammenhengen mellom respondentenes bakgrunn, yrkeserfaring og yrkesgruppe, deres kiennskap til formalkrav til selvmordsrisikovurdering, og deres oppfatning og holdning til prosedyrene. Pearsons Chikvadrat test ble benyttet. Signifikansnivået ble satt til $\mathrm{p}<0,05$. Analysene ble utført med SAS 9.4.

\section{Etikk}

Prosjektet var godkjent av ledelsesgruppen i Klinikk for psykisk helsevern og rusbehandling (PLM) og registrert hos Forskningsavdelingen ved Sykehuset Đstfold. Data ble samlet inn ved et elektronisk anonymisert spørreskjema (Questback). I materialet som ledsaget spørreskjemaet ble deltakerne informert om hensikten med studien. De ble også informert om at personer som besvarte undersøkelsen derved også samtykket $\mathrm{i}$ at data ble brukt i den aktuelle undersøkelsen og publisert. 


\section{Resultater}

\section{Deltakernes bakgrunn}

De 396 deltakerne besto av 50 leger eller psykiatere (12,6\%), 89 psykologer eller psykologspesialister $(22,5 \%)$, og 105 sykepleiere eller psykiatriske sykepleiere $(26,5 \%)$. Gruppen «annet» er på 152 personer $(38,3 \%)$, hvor de klart mest frekvente yrkesgrupper var vernepleiere (inkludert vernepleiere med videreutdanning) og sosionomer (inkludert sosionomer med videreutdanning).

Som det fremgår av tabell 1 arbeidet omtrent halvparten av deltakerne i psykiatrisk poliklinikk (DPS), ACT, eller ambulante team og den andre halvparten i døgnseksion. Noe over halvparten av deltakerne hadde arbeidet i sin nåværende jobb i mer enn fem år. Omtrent en tredel av deltakerne hadde opplevd å miste en pasient i selvmord. Ca. en tredel møtte selvmordsnære pasienter ofte, fra hver dag $(22,7 \%)$ til en til to ganger i uken ( $9,2 \%)$.

Når det gielder kjønnsfordelingen, var 145 menn (36,6 \%) og 251 kvinner (63,6 \%). Litt flere av de mannlige respondentene arbeidet i dognseksjon, hadde litt oftere opplevd å miste pasienter i selvmord, og møtte også litt oftere selvmordsnære pasienter. Det var ingen kjønnsforskjeller når det gialdt yrkeskategori eller antall år i jobben.

TABELL 1. Respondentenes bakgrunn.

\begin{tabular}{|c|c|c|c|c|}
\hline Bakgrunn & $\begin{array}{c}\text { Total, } \mathbf{n}=396 \\
N(\%)\end{array}$ & $\begin{array}{c}\text { Kvinne, } \mathbf{n}=251 \mathrm{~N} \\
(\%)\end{array}$ & Mann, $n=145 \mathrm{~N}(\%)$ & $\begin{array}{c}\text { Test av } \\
\text { kjønnsforskjeller }\end{array}$ \\
\hline \multicolumn{5}{|l|}{ Yrkestype } \\
\hline Lege eller psykiater & $50(12.6)$ & $25(10.0)$ & $25(17.2)$ & \multirow{4}{*}{$\begin{array}{r}x^{2}=4.77 \\
p=0.19\end{array}$} \\
\hline Psykolog eller psykologspesialist & $89(22.5)$ & $57(22.7)$ & $32(22.1)$ & \\
\hline Sykepleier eller psykiatrisk sykepleier & $105(26.5)$ & $71(28.3)$ & $34(23.5)$ & \\
\hline Annen yrkestittel & $152(38.4)$ & $98(39.0)$ & $54(37.2)$ & \\
\hline \multicolumn{5}{|l|}{ Type arbeidsplass } \\
\hline Ambulant akutteam/ACT & $29(7.3)$ & $18(7.2)$ & $11(7.6)$ & \multirow{4}{*}{$\begin{array}{r}x^{2}=7.83 \\
p=0.05\end{array}$} \\
\hline Ambulant team & $25(6.3)$ & $13(5.2)$ & $12(8.3)$ & \\
\hline Poliklinikk & $143(36.1)$ & $103(41.0)$ & $40(27.6)$ & \\
\hline Døgnseksjon & $199(50.3)$ & $117(46.6)$ & $82(56.5)$ & \\
\hline \multicolumn{5}{|l|}{ Antall år arbeidet i denne jobben } \\
\hline under 3 år & $108(27.3)$ & $67(26.7)$ & $41(28.3)$ & \multirow{4}{*}{$\begin{array}{r}x^{2}=0.83 \\
p=0.84\end{array}$} \\
\hline 3-5 år & 75 (18.9) & $45(17.9)$ & $30(20.7)$ & \\
\hline 6-10 år & $103(26.0)$ & $68(27.1)$ & $35(24.1)$ & \\
\hline Over 10 år & $110(27.8)$ & $71(28.3)$ & $39(26.9)$ & \\
\hline \multicolumn{5}{|l|}{ Har du mistet pasienter i selvmord? } \\
\hline $\mathrm{Ja}$ & $119(30.1)$ & $66(26.3)$ & $53(36.6)$ & \multirow{2}{*}{$\begin{array}{r}x^{2}=4.60 \\
p=0.03\end{array}$} \\
\hline $\mathrm{Nei}$ & $277(69.9)$ & $185(73.7)$ & $92(63.4)$ & \\
\hline \multicolumn{5}{|c|}{ Hvor ofte møter du selvmordsnære pasienter } \\
\hline Nesten daglig & $90(22.7)$ & $46(18.3)$ & $44(30.3)$ & \multirow{5}{*}{$\begin{array}{r}\chi^{2}=8.31 \\
p=0.08\end{array}$} \\
\hline 1-2 ganger pr uke & $176(9.2)$ & $52(20.7)$ & $24(16.6)$ & \\
\hline 1-2 ganger pr måned & $83(21.0)$ & $57(22.7)$ & $26(17.9)$ & \\
\hline Noen ganger i året & $114(28.8)$ & $76(30.3)$ & $38(26.2)$ & \\
\hline Svært sjeldent & $33(8.3)$ & $20(8.0)$ & $13(9.0)$ & \\
\hline
\end{tabular}




\section{Kjennskap til formalkrav og holdninger til rutiner} og prosedyrer for vurdering av selvmordsrisiko Helhetsbildet er at deltakerne rapporterte om god kjennskap til formalkrav til vurdering av selvmordsrisiko, som vist i tabell 2 . Når det gielder kjennskap til gieldende lovverk rapporterte $40,4 \%$ at de var enten svært godt eller godt kjent med gieldende lovverk. Tilsvarende prosentandel var 38,2 \% for nasionale retningslinjer og 53,6 \% for prosedyrene i EK. Over $80 \%$ oppga å være enten svært godt eller godt kjent med rutiner ved egen seksion. Under fem prosent oppga å ikke være kjent med prosedyrene i EK eller rutiner ved egen seksjon.

Når det gielder holdninger var $53 \%$ helt enige og 35,1 \% delvis enige i påstanden «Gode rutiner giør arbeidet mer målrettet». Vedrørende påstanden «Prosedyrene og retningslinjene avklarer ansvar på en god måte» var $26,5 \%$ helt enig og $48,5 \%$ delvis enig i denne. Videre var 41,9\% helt enig og 42,9 \% delvis enige i påstanden «Dokumentasjon hielper meg ved å gi meg trygghet på at jeg har fått med meg det som er relevant i en selvmordsrisikovurdering». Mindre enn $2 \%$ av deltakerne var helt uenig i disse tre utsagnene, slik at totalinntrykket er en aksepterende holdning til rutiner og prosedyrer for vurdering av selvmordsrisiko. På den annen side var over halvparten enten helt enig (11,9\%) eller delvis enig $(41,7 \%)$ i utsagnet «Vi bruker for mye tid på dokumentasion og for lite på pasientene», mens 26-27\% var enten helt enig eller delvis enig i utsagnene «Dokumentasion er bare til for at vi skal ha 'ryggen fri' dersom det går ille med pasienten» og «Dokumentasion er ledernes behov for gode måltall». Henholdsvis 53,5\% og 46,2 \% var enten helt eller delvis uenig i disse to påstandene.

Det var ingen statistisk signifikante kiønnsforskjeller når det gielder kjennskap til formalkrav for vurdering av selvmordsrisiko (Tabell 2). Det var heller ikke statistisk signifikante kjønnsforskjeller når det gialdt svarene på påstandene «Gode rutiner giør arbeidet mer målrettet», «Prosedyrene og retningslinjene avklarer ansvar på en god måte» og «Dokumentasion hjelper meg ved å gi meg en trygghet på at jeg har fått med meg det som er relevant i en selvmordsrisikovurdering». Men vi fant noen signifikante kjønnsforskjeller i svarene på noen av de andre påstandene. For eksempel var flere menn enn kvinner helt enig i

TABELL 2. Kjennskap og holdninger til rutiner og prosedyrer for vurdering av selvmordsrisiko.

\begin{tabular}{|c|c|c|c|c|c|}
\hline Kjennskap og holdninger & & & rdeling, $\mathbf{N}(\%)$ & & \\
\hline Kjennskap til formalkravene & Svært godt kjent & Godt kjent & Kjent & Litt kjent & Ukjent \\
\hline Q1_1: Gjeldende lovverk & $31(7.8)$ & $129(32.6)$ & $151(38.1)$ & $71(17.9)$ & $14(3.6)$ \\
\hline Q1_2: Nasjonale retningslinjer & $30(7.6)$ & $121(30.6)$ & $148(37.3)$ & $80(20.2)$ & $17(4.3)$ \\
\hline Q1_3: Prosedyre i EK & $53(13.4)$ & $159(40.2)$ & $119(30.0)$ & $54(13.6)$ & $11(2.8)$ \\
\hline Q1_4: Rutiner ved egen seksjon & $145(36.6)$ & $173(43.7)$ & $57(14.4)$ & $18(4.5)$ & $3(0.8)$ \\
\hline Holdninger til formalkravene & Helt enig & Delvis enig & $\begin{array}{l}\text { Verken enig } \\
\text { eller uenig }\end{array}$ & Delvis uenig & Helt uenig \\
\hline $\begin{array}{l}\text { Q2_1: Gode rutiner gjør arbeidet } \\
\text { mer målrettet }\end{array}$ & $210(53.0)$ & $139(35.1)$ & $34(8.6)$ & $6(1.5)$ & $7(1.8)$ \\
\hline $\begin{array}{l}\text { Q2_2: Prosedyrene og retningslinjene } \\
\text { avklarer ansvar på en god måte }\end{array}$ & $105(26.5)$ & $192(48.5)$ & $62(15.6)$ & $30(7.6)$ & $7(1.8)$ \\
\hline $\begin{array}{l}\text { Q2_3: Dokumentasjonen hjelper meg } \\
\text { ved å gi meg en trygghet på at jeg } \\
\text { har fått med det som er relevant i en } \\
\text { selvmordsrisikovurdering }\end{array}$ & $166(41.9)$ & $170(42.9)$ & $35(8.8)$ & $18(4.6)$ & $7(1.8)$ \\
\hline $\begin{array}{l}\text { Q2_4: Vi bruker altfor mye tid på doku- } \\
\text { mentasjon og for lite på pasientene }\end{array}$ & $47(11.9)$ & $165(41.7)$ & $86(21.7)$ & $80(20.2)$ & $18(4.5)$ \\
\hline $\begin{array}{l}\text { Q2_5: Dokumentasjon er bare til for at } \\
\text { vi skal ha «ryggen fri» hvis det går ille } \\
\text { med pasienten }\end{array}$ & $15(3.8)$ & $89(22.5)$ & $80(20.2)$ & $110(27.8)$ & $102(25.7)$ \\
\hline $\begin{array}{l}\text { Q2_6: Dokumentasjonen er ledernes } \\
\text { behov for gode måltall }\end{array}$ & $16(4.0)$ & $91(23.0)$ & $106(26.8)$ & $95(24.0)$ & 88 (22.2) \\
\hline
\end{tabular}


påstanden «Vi bruker for mye tid på dokumentasjonen og for lite på pasientene» (17,3 \% versus 8,37 \%, $\left.\chi^{2}=10,37, p=0,04\right)$. Det var også statistisk signifikante forskjeller ved at flere menn enn kvinner var helt eller delvis enig i at «Dokumentasjon er bare til for at vi skal ha 'ryggen fri' hvis det går ille med pasienten» (37,93 \% versus $19,52 \%, \chi^{2}=15,98, \mathrm{p}<0,01$ ) og «Dokumentasion er ledernes behov for gode måltall» $(37,24 \%$ versus $\left.21,12 \%, \chi^{2}=19,62, p<0,01\right)$.

\section{Forskjeller mellom utdanningsbakgrunn, yrkeserfaring og yrkesgruppe}

Vi fant ingen signifikante forskjeller mellom hverken det å ha mistet en pasient i selvmord eller type arbeidsplass og rapportert kjennskap til formalkrav for selvmordsrisikovurdering eller oppfatninger og holdninger til prosedyrer og rutiner. Vi fant imidlertid betydelig forskjeller i forhold til andre faglige bakgrunner.

Yrkestittel: Det var signifikante forskjeller mellom de forskjellige yrkesgruppenes rapporterte kjennskap til gieldende lovverk, nasjonale retningslinjer og prosedyrer i EK ( $\mathrm{p}<0,01$ for alle), og personalets oppfatning og holdning til rutiner og prosedyrer for alle seks spørsmål i denne delen ( $\mathrm{p}<0,05)$. Som vist i Figur 1 rapporterte lege/psykiater å ha best kjennskap til gieldende lovverk (70 \% svært godt kjent med eller godt kjent med), fulgt av psykolog/psykologspesialist (39,3\%) og sykepleier/psykiatrisk sykepleier (39\%) som lå omtrent likt, og deretter kategorien andre (32,2 \%). Et lignende mønster ble også funnet når det gialdt rapportert kjennskap til nasjonale retningslinjer, prosedyrer i EK, og rutiner ved egen seksion.

Det var også signifikante forskieller mellom deltakernes yrkesgruppe og oppfatning og holdning til rutiner og prosedyrer. Som vist i figur 1 var leger/psykiatere i minst grad helt enig med påstanden «Gode rutiner giør arbeidet mer målrettet», fulgt av psykologer/psykologspesialister (49,4\%), sykepleiere/psykiatriske sykepleiere (55,2\%), og kategorien andre som i størst grad var enige (61,2\%). Et lignende mønster avtegner seg når en ser på andelen respondenter som var helt enige i påstanden om at «Prosedyrene og retningslinjene avklarer ansvar på en god måte». Oppfatning i utsagnet «Vi bruker for mye tid på dokumentasjon og for lite på pasientene» var også mest utbredt blant leger/psyki-

FIGUR 1. Rapportert kjennskap og holdninger til rutiner og prosedyrer for vurdering av selvmordsrisiko gruppert etter yrkestittel.




atere (75 \% i helt eller delvis enig), slik det også var med de to restutsagnene «Dokumentasion er bare til for at vi skal ha 'ryggen fri' dersom det går ille med pasienten» og «Dokumentasjon er ledernes behov for gode måltall» (Q2_5 og Q2_6 i figur 1).

Hvor ofte en møter selvmordsnære pasienter: Det er åpenbart at kjennskap til formalkrav for selvmordsrisiko vil korrelere med hvor ofte personalet møter selvmordsnære pasienter i sitt arbeide - jo oftere en møter selvmordsnære pasienter i sitt arbeide jo bedre kiennskap vil en forventelig ha til gieldende lover, nasjonale retningslinjer, prosedyrer i EK, og rutiner ved egen seksion (se tabell 3). For personale som møtte selvmordsnære pasienter nesten daglig rapporterte over $50 \%$ at de var enten svært godt eller godt kjent med gieldende lovverk, nasjonale retningslinjer og prosedyrer i EK, og nesten $90 \%$ oppgir å være svært godt eller godt kjent med rutiner ved egen seksion. De tilsvarende prosentandeler er enten like eller noe lavere hos dem som møter selvmordsnære pasienter 1-2 ganger pr. uke. For de som rapporterte at de svært sjelden møtte selvmordsnære pasienter, rapporterte kun $10-30 \%$ at de var enten svært godt eller godt

Tabell 3. Rapportert kjennskap til rutiner og prosedyrer for vurdering av selvmordsrisiko gruppert etter hvor ofte en møter selvmordsnære pasienter.

\begin{tabular}{|c|c|c|c|c|c|c|}
\hline Rutiner og prosedyrer & $\begin{array}{l}\text { Nesten } \\
\text { daglig }\end{array}$ & $\begin{array}{c}\text { 1-2 ganger } \\
\text { pr uke }\end{array}$ & $\begin{array}{l}\text { 1-2 ganger } \\
\text { pr måned }\end{array}$ & $\begin{array}{c}\text { Noen } \\
\text { ganger i året }\end{array}$ & $\begin{array}{l}\text { Svært } \\
\text { sjeldent }\end{array}$ & $\begin{array}{c}\text { Test av } \\
\text { forskjeller }\end{array}$ \\
\hline \multicolumn{7}{|l|}{ Q1_1: Gjeldende lovverk } \\
\hline Svært godt kjent med & $13(14.5)$ & $3(3.9)$ & $8(9.6)$ & $6(5.3)$ & $1(3.0)$ & \multirow{5}{*}{$\begin{array}{r}x^{2}=47.13 \\
p<0.01\end{array}$} \\
\hline Godt kjent med & $38(42.2)$ & $31(40.8)$ & $25(30.1)$ & $29(25.4)$ & $6(18.2)$ & \\
\hline Kjent med & $25(27.8)$ & $29(38.2)$ & $39(47.0)$ & $43(37.7)$ & $15(45.5)$ & \\
\hline Litt kjent med & $13(14.4)$ & $13(17.1)$ & $9(10.8)$ & $30(26.3)$ & $6(18.2)$ & \\
\hline Ukjent med & $1(1.1)$ & $0(0.0)$ & $2(2.4)$ & $6(5.3)$ & $5(15.1)$ & \\
\hline \multicolumn{7}{|c|}{ Q1_2: Nasjonale retningslinjer } \\
\hline Svært godt kjent med & $14(15.6)$ & $3(3.9)$ & $7(8.4)$ & $5(4.4)$ & $1(3.0)$ & \multirow{5}{*}{$\begin{array}{r}x^{2}=48.05 \\
p<0.01\end{array}$} \\
\hline Godt kjent med & $30(33.3)$ & $31(40.8)$ & $26(31.3)$ & $31(27.2)$ & $3(9.1)$ & \\
\hline Kjent med & $31(34.5)$ & $22(28.9)$ & $38(45.8)$ & $42(36.8)$ & $15(45.5)$ & \\
\hline Litt kjent med & $13(14.4)$ & $18(23.7)$ & $11(13.3)$ & $30(26.3)$ & $8(24.2)$ & \\
\hline Ukjent med & $2(2.2)$ & $2(2.6)$ & $1(1.2)$ & $6(5.3)$ & $6(18.2)$ & \\
\hline \multicolumn{7}{|l|}{ Q1_3: Prosedyrer i EK } \\
\hline Svært godt kjent med & $16(17.8)$ & $8(10.5)$ & $12(14.5)$ & $16(14.1)$ & $1(3.0)$ & \multirow{5}{*}{$\begin{array}{r}x^{2}=25.77 \\
p=0.06\end{array}$} \\
\hline Godt kjent med & $40(44.4)$ & $41(53.9)$ & $30(36.1)$ & $40(35.1)$ & $8(24.2)$ & \\
\hline Kjent med & $24(26.7)$ & $16(21.1)$ & $28(33.7)$ & $34(29.8)$ & $17(51.5)$ & \\
\hline Litt kjent med & $7(7.8)$ & $10(13.2)$ & $11(13.3)$ & $21(18.4)$ & $5(15.2)$ & \\
\hline Ukjent med & $3(3.3)$ & $1(1.3)$ & $2(2.4)$ & $3(2.6)$ & $2(6.1)$ & \\
\hline \multicolumn{7}{|c|}{ Q1_4: Rutiner ved egen seksjon } \\
\hline Svært godt kjent med & $43(47.8)$ & $28(36.9)$ & $30(36.1)$ & 38 (33.3) & $6(18.2)$ & \multirow{5}{*}{$\begin{array}{r}x^{2}=31.63 \\
p=0.01\end{array}$} \\
\hline Godt kjent med & $36(40.0)$ & $37(48.7)$ & $39(47.0)$ & $47(41.2)$ & $14(42.4)$ & \\
\hline Kjent med & $6(6.7)$ & $9(11.8)$ & $11(13.3)$ & $20(17.6)$ & $11(33.3)$ & \\
\hline Litt kjent med & $3(3.3)$ & $2(2.6)$ & $3(3.6)$ & $9(7.9)$ & $1(3.0)$ & \\
\hline Ukjent med & $2(2.2)$ & $0(0.0)$ & $0(0.0)$ & $0(0.0)$ & $1(3.0)$ & \\
\hline
\end{tabular}




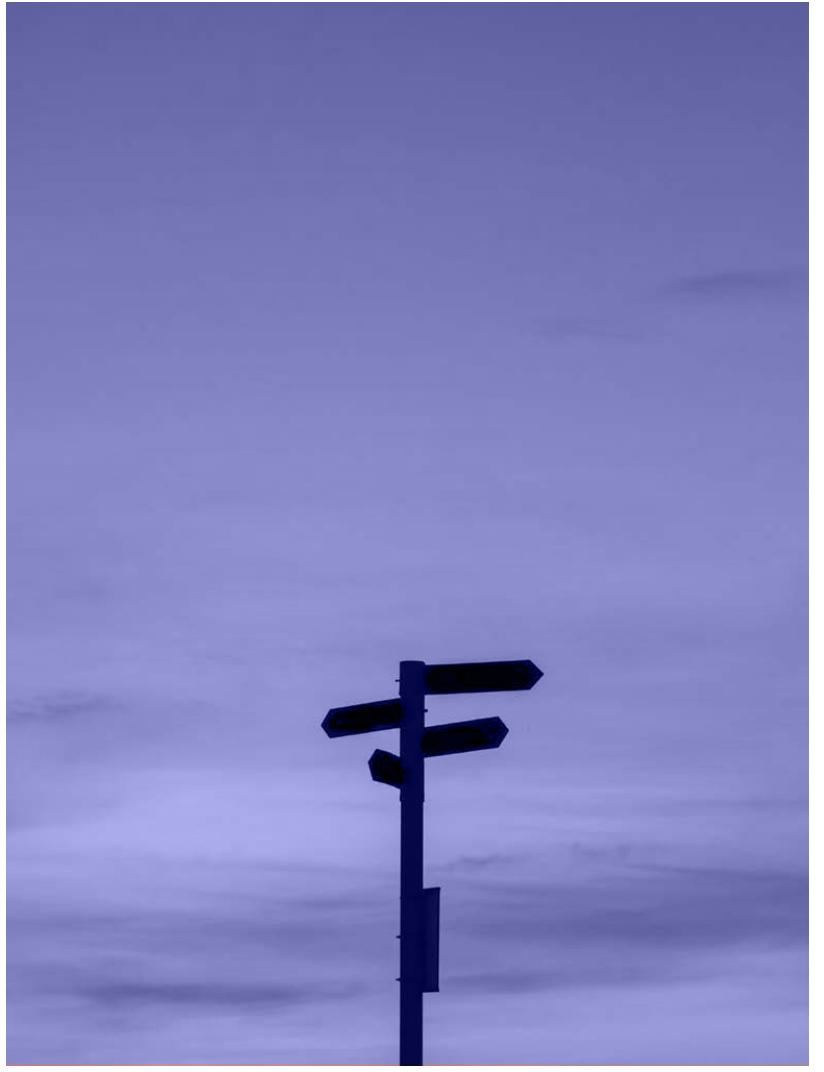

kjent med gieldende lover, nasjonale retningslinjer og prosedyrer i EK, mens $60 \%$ rapporterte at de var svært godt kjent med rutiner ved egen seksion. Oppfatninger/ holdninger til rutiner og prosedyrer var ikke signifikant relatert til hvor ofte en møtte selvmordsnære pasienter i arbeidet.

Antall år på denne arbeidsplassen: Vi fant ingen statistisk signifikant sammenheng i rapportert kjennskap til formalkrav for selvmordsrisikovurdering og antall år i arbeidet. Men det var en statistisk signifikant sammenheng mellom denne faktoren og oppfatning og holdninger til prosedyrer og rutiner. Deltakere med lengre yrkeserfaring var i større grad enig i påstanden om at «Gode rutiner giør arbeidet mer målrettet» $(\mathrm{p}<0,01)$ og påstanden om at «Prosedyrene og retningslinjene avklarer ansvar på en god måte» $(\mathrm{p}=0,07)$.

\section{Diskusjon}

Personalets kjennskap og holdning til formalkravene for vurdering av selvmordsrisiko.

Resultatene indikerer at våre respondenter rapporterer god kjennskap til formalkrav om vurdering av selvmordsrisiko. Deltakerne rapporterte best kjennskap til rutiner i egen seksion etterfulgt av prosedyrer i EK, gieldende lovverk og nasionale retningslinjer. Dette er de fire mest avgiørende kategoriene av retningsgivende dokumenter for vurdering av selvmordsrisiko, i spennet fra lokalt til nasjonalt nivå. Generelt rapporterte deltakerne høy grad av kjennskap til den delen av formalkrav som er mest avgiørende for den kliniske praksisen, dvs. rutiner i egen seksion. Imidlertid var rapportert kjennskap til både nasionale retningslinjer og gieldende lovverk noe lavere. Slik kjennskap var ikke forskjellig mellom mannlige og kvinnelige deltakere.

Da nasjonale retningslinjer kom ut i 2008 medvirket dette sannsynligvis til at praksis ble endret i mange fylker og modellert etter anbefalingene til rutiner og prosedyrer som ble gitt i retningslinjene. Det vil særlig være kjennskap til prosedyrer i EK og rutiner ved egen seksion som er utslagsgivende for den kliniske praksisen. Ved Sykehuset $\bigoplus$ stfold ble seksionsvise prosedyrer fjernet og erstattet med felles overliggende prosedyrer i EK i 2008, i forbindelse med at nasjonale retningslinier kom ut. Dette ble giort for å giennomføre enhetlig begrepsbruk og motvirke misforståelser. Forskjellen mellom prosedyrer i EK og rutiner i egen seksjon er nå kun logistisk/teknisk ved at de mest benyttede prosedyrene i EK er giort lettere tilgiengelig i seksionene, eller ved at en enhet (ACT) har en egen marginalt forskjellig variant av rutinene tilpasset deres arbeidsområde. Når vi har presentert resultatene av undersøkelsen i faglige fora på Sykehuset Đstfold og spurt hvorfor undersøkelsen viser en forskjell mellom prosedyrer i EK og rutiner i egen seksion forklares dette ved at de prosedyrer som benyttes blir betraktet som rutiner i egen seksjon, selv om de samtidig er en del av en omfattende prosedyresamling i EK. Derfor er kjennskap til rutiner i egen seksion den faktor som er mest styrende for klinisk praksis. Av våre respondenter angir 36,6 \% å være svært godt kjent, 43,7 \% godt kjent, $14,4 \%$ kjent, 4,5\% litt kjent, og o,8 \% ukjent med rutiner i egen seksion.

Resultatene av studien viser at respondentenes rapporterte kjennskap til formalkrav til selvmordsrisikovurdering varierer signifikant med yrkesbakgrunn, yrkeserfaring, og med hvor ofte de møter selvmordsnære pasienter. Det er forventet at de som ofte møter selvmordsnære pasienter har en bedre kjennskap til formalkrav. I nasjonale retningslinjer er det angitt, som nevnt i innledningen, at kartlegging og observasion skal utføres av alt klinisk personale, mens vurdering av selvmordsrisiko skal utføres av leger, psykologer og andre med særskilte kvalifikasioner. Den siste kategorien er det opp til det enkelte helseforetak å definere. Ved Sykehuset Østfold omfatter denne kategorien medarbeidere innen ambulante akutt-team og ACT med 3-årig høyskoleutdanning og videreutdanning i psykisk helsearbeid, som i tillegg til denne utdanningen har giennomgått et særskilt kvalifiseringsprogram for vurdering av selvmordsrisiko (Sykehuset Đstfold, 2016).

I kategoriseringen av yrker har vi valgt kategorien psykiatrisk sykepleier til tross for at videreutdanningen i psykisk helsearbeid har vært tverrfaglig siden 


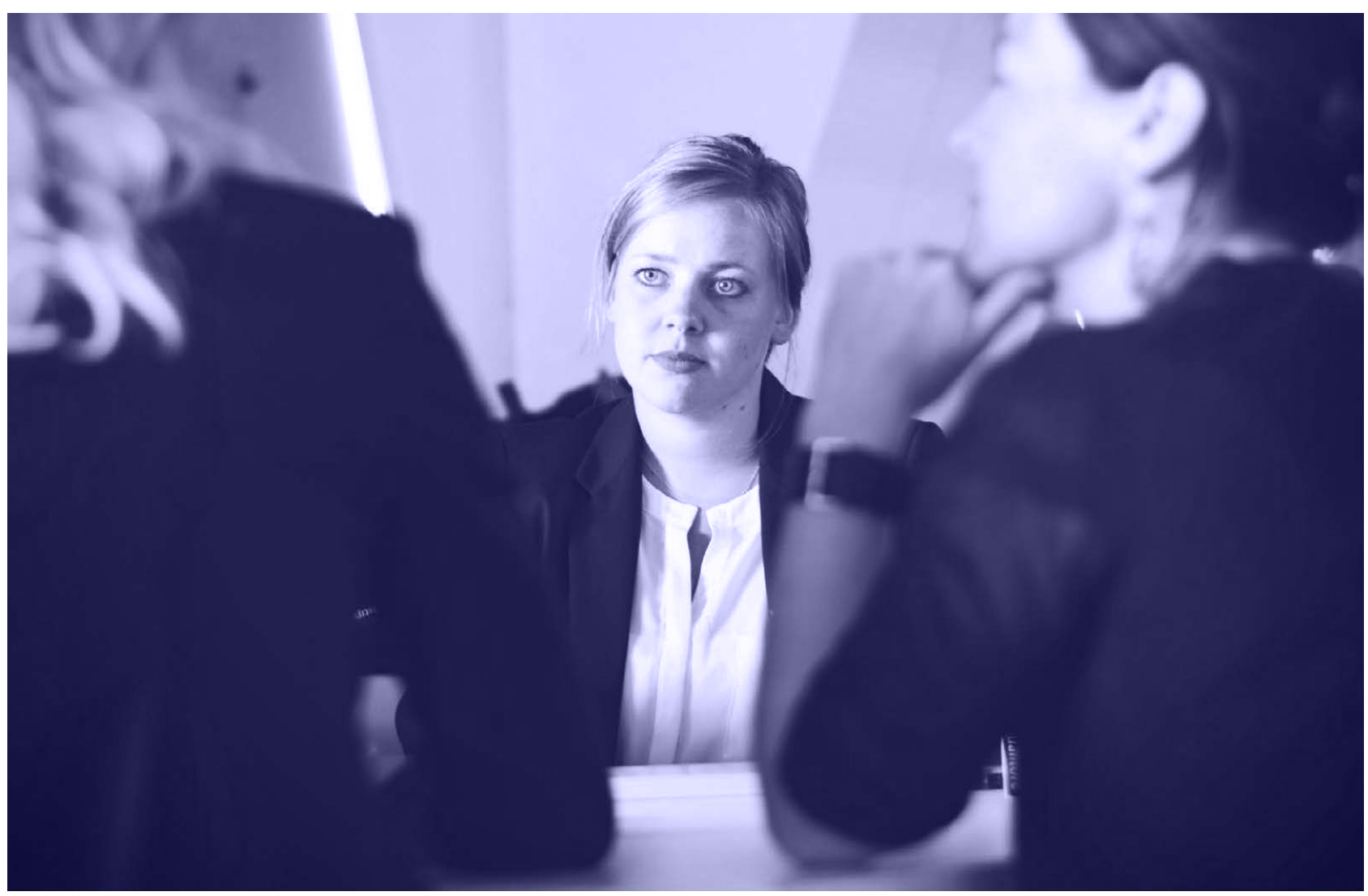

2005 (Utdannings- og forskningsdepartementet, 2005). Kategorien psykiatrisk sykepleier benyttes i dagligtalen i psykisk helsevern, slik at det er overveiende sannsynlig at sykepleiere med videreutdanning har krysset av i denne yrkeskategorien. Når det gielder yrkesgrupper ser en i resultatene det forventelige i det at de yrkesgruppene som har ansvaret for vurdering (i denne sammenheng i motsetning til kartlegging) av selvmordsrisiko, også har en høy grad av rapportert kjennskap til formalkravene.

Når det gialdt forskjellene mellom deltakernes yrkesgruppe og oppfatning og holdning til rutiner og prosedyrer, hadde lege/psykiater mer kritiske og negative holdninger til noen aspekter ved prosedyrene. For eksempel var ca. $54 \%$ av respondentene helt eller delvis enig i utsagnet «Vi bruker for mye tid på dokumentasjon og for lite på pasientene». En slik oppfatning var mest utbredt blant leger/psykiatere (75\%), etterfulgt av psykologer/psykologspesialister, deretter kategorien andre, og til sist sykepleiere/psykiatrisk sykepleiere. Videre var over $25 \%$ av respondentene enig i påstanden «Dokumentasion er bare til for at vi skal ha 'ryggen fri' dersom det går ille med pasienten» og at «Dokumentasion er ledernes behov for gode måltall». Igien skårer lege/psykiater høyest her. Myhre (2016) finner også det samme når det gielder lege/psy-

kiater, men finner en annen fordeling når det gielder de andre yrkesgruppene (s. 33).

Det at lege/psykiater og psykolog/psykologspesialist er de yrkesgruppene som er mest kritiske til prosedyrene, kan ses i sammenheng med at det er nettopp disse yrkesgruppene som i henhold til nasjonale retningslinjer får oppgaven med å foreta vurdering av selvmordsrisiko.

Som folge av det juridiske fokuset i psykisk helsevern i dag, kan det tenkes at pasienter i for stor grad blir sendt videre fra kartlegging til vurdering "for sikkerhets skyld».

i dag, kan det tenkes at pasienter i for stor grad blir sendt videre fra kartlegging til vurdering «for sikkerhets skyld» - litt i tråd med det som i den engelskspråklige litteraturen blir kalt «defensive medicine» (Bleich et al., 2011); klinikerens handlinger bestemmes av hensynet til å dekke seg selv juridisk mer enn av hensynet til det 
som er beste behandling for pasienten (Larsen, 2010; Stangeland, 2012). Mange leger og psykologer forteller at de blir satt til å giøre så mange selvmordsrisikovurderinger at dette opptar en uforholdsmessig stor del av arbeidstiden. Det å giøre en god selvmordsrisikovurdering av pasienter de ikke har kjennskap til fra for vil også være svært arbeidskrevende. Leger og psykologer kan også føle at det ligger en asymmetri i dette; annet personale kan ha bedre kjennskap til pasienten, mens de selv er ansvarlige for å utføre selvmordsrisikovurderingen. Denne dynamikken hvor leger og psykologer blir sittende som «siste ledd i ansvarskjeden» kan være en grunn til at det er de som i størst grad oppfatter de negative aspekter ved prosedyrene. I tillegg til selve vurderingen kan irritasjon over den tid som går med til å skrive inn dokumentasjon i DIPS virke i samme retning når det gielder holdning til prosedyrene.

Når det gielder klinisk erfaring, var holdninger til rutiner og prosedyrer ikke signifikant relatert til hvor ofte en møtte selvmordsnære pasienter i arbeidet, men respondenter med lengre yrkeserfaring i større grad var enig i påstandene «Gode rutiner giør arbeidet mer målrettet» og «Prosedyrene og retningslinjene avklarer ansvar på en god måte». En kunne tenke seg at mer uerfarne klinikere/personale var de som var mest positive til de siste utsagnene, fordi prosedyrene hielper til med å strukturere en kompleks og mangefasettert klinisk situasjon, mens mer erfarne klinikere kunne forventes å være mer kritiske, fordi de samme prosedyrene kunne begrense

\section{Dette impliserer at} rutiner og prosedyrer ikke kun er til hielp i begynnelsen av karrieren, men at også erfarne klinikere opplever nytten av dem.

\section{klinisk autonomi}

i en situasjon som personalet følte at de behersket uten strukturerende prosedyrer. Det vi fant var det motsatte; klinikere med lengre yrkeserfaring var i større grad enig i disse påstandene. Dette

impliserer at rutiner og prosedyrer ikke kun er til hjelp i begynnelsen av karrieren, men at også erfarne klinikere opplever nytten av dem.

\section{Styrker og begrensninger ved studien}

Den foreliggende studien er etter det vi kjenner til den mest omfattende studien som undersøker personale i psykisk helsevern om deres kjennskap til formalkrav i vurdering av selvmordsrisiko, samt deres holdninger til disse. Mens tidligere studier har fokusert på et mindre utvalg, fra én enkelt til få profesjoner, omfatter denne studien hele bredden av profesjoner i psykisk helsevern; fra psykiatere, psykologer, sykepleiere og andre profesjoner som vernepleiere og sosionomer. Dette muliggjorde å få innsikt i rapportert kjennskap og holdninger til rutiner og prosedyrer for vurdering av selvmordsrisiko, og hvordan disse henger sammen med faktorer som yrkeskategori og arbeidsplass, samt klinisk erfaring med selvmordsnære pasienter. Responsraten på 36,3 \% anses som akseptabel for denne type studie (se for eksempel Fryrear, 2015). Likevel kan vi ikke fastslå hvorvidt det foreligger signifikante forskjeller i rapportert kjennskap eller holdninger til rutiner og prosedyrer mellom de som svarte på undersøkelsen og de som ikke giorde det. Undersøkelsen ble giennomført i ett enkelt fylke og der er derfor usikkert hvorvidt resultatene er representative for andre fylker. Sammenlignet med studien fra Vestfold (Myhre, 2016) viser vår studie imidlertid klart de samme overliggende tendensene.

\section{Tolkning av svarene}

Hvordan skal vi tolke respondentenes enighet eller uenighet i disse påstandene? Undersøkelser av denne typen har ingen på forhånd gitt «baseline» som en kan måle resultatene opp mot og konkludere med om det en har funnet er «mye» eller «lite». En konklusjon her blir svært avhengig av den subjektive oppfatning til den som tolker data har om hva som var forventet. Vi synes, på bakgrunn av diskusjoner med klinikere både i formelle og uformelle fora, at deres aksept av rutiner og prosedyrer og begrunnelsene for å anvende rutiner og prosedyrer, var høy i forhold til det vi hadde forventet.

La oss ta et eksempel på det subjektive og relative i fortolkningen av resultatene ved å velge en av påstandene med en ekstrem/aksentuert fordeling av enighet og uenighet. Vi kan ta den påstanden respondentene var mest uenig i: «Dokumentasjon er bare til for at vi skal ha 'ryggen fri' dersom det går ille med pasienten». 53,6 \% er enten delvis uenig (27,8\%) eller helt uenig $(25,8)$. På bakgrunn av dette kan en si at respondentene massivt avviser påstanden (og dens ensidige legalistiske og juridiske innhold). Men legg merke til hvor ekstrem påstanden er; at dokumentasjon bare er til for at en skal ha «ryggen fri» vil si at den er meningsløs på andre måter, for eksempel å være til nytte i pasientbehandlingen. Ser en svarene i lys av dette momentet, kan en også argumentere for at det er overraskende at 3,8 \% er helt enig og 22,5\% er delvis enig i en så spissformulert påstand. Det er således avgiørende å være bevisst sine egne forventninger i tolkningen av resultatene.

Som nevnt innledningsvis har det foregått en debatt om vurderinger av selvmordsrisiko kan komme i konflikt med terapi og «care». Siden klinikerens tid er begrenset vil en kunne se for seg en situasjon hvor disse hensyn ikke forenes, men går på bekostning av hverandre. Våre funn indikerer at klinikere er ambivalente til prosedyrer og rutiner; de ser fordelen med at prosedyrer strukturerer risikovurderingen og giør den mer målrettet og fokusert, men beklager seg samtidig over den tid det tar samt det «juridiske» fokus prosedyrene kan skape. Som nevnt synes vi, på 
bakgrunn av blant annet denne debatten, at personalet hadde mer positive holdninger til prosedyrene enn vi hadde forventet. Denne ambivalensen er også funnet i den andre studien i psykisk helsevern vi fant i den internasjonale litteraturen. Wand et al. (2015) oppsummerer sine resultater slik:

...respondents generally agreed that risk assessment and management practices make a difference to the outcome for consumers, and were reassured by such practices. There were also high levels of agreement that risk assessment and management is essential to maintaining safety and delivering good care. High levels of confidence in their judgement were also expressed by respondents when carrying out risk assessment and management practices. Somewhat paradoxically, respondents identified organizational pressure and a 'culture of blame' around risk assessment and management, and of being left to feel responsible following an adverse event, but felt supported by the mental health service (s. 148).

En lignende ambivalens er også funnet i andre sektorer i helsevesenet. I en spørreskjemaundersøkelse blant medisinsk personale ved en kvinneklinikk i England finner Hackett (1999) at «...there was a real concern that clinical freedom will be eroded by clinical governance, but more consistent clinical performance will be secured» (s. 212).

Siden selvmord er et multifaktorielt betinget fenomen, er det vesentlig at bredspektret selvmordsforebyggende tiltak settes inn på alle nivåer i samfunnet, men psykisk helsevern og rusbehandling må nok sies å utgiøre en spesielt viktig arena. Det er en betydelig sammenheng mellom kontakt med spesialisthelsetjenesten i psykisk helsevern og selvmord. I en studie av alle selvmord i Oslo i perioden 1992-1998 fant Walby et al. (2006) at ved en firedel av alle selvmordene hadde personen enten vært innlagt i psykiatrien i lopet av de siste tre år før selvmordet skjedde (77,9 \%) eller var innlagt da selvmordet skjedde (22,1\%). Forskning utført i den senere tid kan tyde på at sammenhengen er enda sterkere (Walby, 2017; Nasjonalt senter for selvmordsforskning og forebygging, 2018), noe som ytterligere understreker viktigheten av selvmordsforebyggende tiltak innen psykisk helsevern og rusbehandling.

\section{Konklusjon}

Vi fant at respondentene giennomgående rapporterte god kjennskap til formalkrav til selvmordsrisikovurderinger, selv om det alltid vil være rom for forbedringer. Respondentene viste en ambivalent holdning til rutiner og prosedyrer for selvmordsrisikovurderinger ved at de både så fordeler (målrettethet og trygghet på å få med seg det som er relevant) og ulemper ved dem (tidkrevende og juridisk fokus). Hovedinntrykket er likevel en positiv grunnholdning, «alt i alt».
Levert: 02.07.18 - Revidert: 30.11.18 - Godkjent: 01.12.18

Takk til: Mange har hjulpet til med velvillig tilrettelegging og innsamling av data på Sykehuset Østfold: Kst. direktør Irene Dahl Andersen, Avdelingssjef Knut-Erik Hymer, og Forskningsavdelingen. Tusen takk også til Fagbiblioteket og Psykiatrisk ekspedisjon og ikke minst til de som besvarte spørreskjemaet

\section{REFERANSER:}

Bleich, A., Baruch, Y., Hirschmann, S., Lubin, G., Melamed, Y., Zemishlany, Z. \& Kaplan, Z. (2011). Management of the suicidal patient in the era of defensive medicine; focus on suicide risk assessment and boundaries of responsibility. Israel Medical Association Journal, 13, 633-636.

Chundury, S., Browne, S., Pollio, D.E., Hong, B.A., Roy, W., Roaten, K., Khan, F. \& North, C.S.: (2017). Suicide risk assessment and management in the psychiatric emergency service: Psychiatric provider experience and perceptions. Archives of Suicide Research. 27. desember: 1-14. doi: 10.1080/13811118.2017.1414648. [Epub ahead of print].

Ekeland, T-I. (2004). Autonomi og evidensbasert praksis. Senter for profesjonsstudier. Høyskolen i Oslo.

Ekeland, T-I. (2009). Hva er evidensen for evidensbasert praksis? I H. Grimen og L. I Terum (red). Evidensbasert profesjonsutøvelse. Oslo: Abstrakt forlag. Kapittel 8: 145-168.

Flynn. R. (2002). Clinical governance and governmentality. Health, risk \& society, 4 (2) doi: 10.1080/13698570220137042

Fryrear, A. (2015). What's a good survey response rate? https://www. surveygizmo.com/resources/blog/survey-response-rates/. Lastet ned 6. november, 2018.

Godin, P.M. (2004). «You don't tick boxes on a form»: A study of how community mental health nurses assess and manage risk. Health, Risk \& Society, 6, 347-360.

Grimen, H. \& Terum, L.I. (red.) (2009). Evidensbasert profesionsutøvelse. Oslo: Abstrakt forlag.

Hackett, M.C. (1999). Implementing clinical governance in trusts. International Journal of Health Care Quality Assurance, 12, 210-213.

Hagen, I. (2018). Care and control - exploring experiences and perceptions of treatment and care of suicidal inpatients in psychiatric wards. Doktorgradsavhandling. Trondheim: Norges teknisk-naturvitenskapelige universitet.

Hagen, I., Hielmeland, H. \& Knizek, B.L. (2017). Relational principles in the care of suicidal inpatients: Experiences of therapists and mental health nurses. Issues in Mental Health Nursing, 38, 99-106.

Hagen, I., Hielmeland, H., Espeland, K. \& Knizek, B.L.(2018). Bedre omsorg, færre selvmord? Tidsskrift for Den norske Legeforening. 5. februar.

Harrison, S.: The politics of evidence-based medicine in the United Kingdom. Polity and Politics, 26, 15-31.

Herrestad, H. \& Larsen, K. (2012). Kartlegging, observasjon og vurdering av selvmordsrisiko. Publisert online på www.rvts.no

Larsen, K. (2010). Antiterapeutiske effekter av selvmordsforebyggende tiltak. www.rvts.no

Lov om helsepersonell (helsepersonelloven) av 2. juli, 1999, paragraf 4.

Lov om spesialisthelsetienesten (spesialisthelsetienesteloven) av 2. juli, 1999, paragraf $2-2$

Muir-Cochrane, E. , Gerace, A., Mosel, K., O`Kane, D., Barkway, P., Curren, \& Oster, C.: (2011). Managing risk: Clinical decision-making in mental health services. Issues in Mental Health Nursing, 32, 726-734 
Myhre, T. (2016). «Mellom frustrasjon og mening». Hvordan opplever behandlere i psykisk helsevern formalkrav knyttet til vurdering av selvmordsfare? Masteroppgave. Nasionalt senter for selvmordsforskning og forebygging. Universitetet i Oslo.

Nasionalt senter for selvmordsforskning og forebygging (2018). Selvmord i spesialisthelsetjenesten innen psykisk helsevern og rus mellom 2008 og 2015. www.uio.no/kartleggingssystemet

Sackett, D.L., Rosenberg. W.M., Muir Gray, I.A., Haynes, R.B. \& Richardson, W.S. (1996). Evidence based medicine: what it is and what it isn't. British Medical Journal, 312, 71-72.

Smith, M.I., Bouch, I., Broadstreet,S., Lakey, T., Nightingale, A. \& O'Connor, R. (2015). Health services, suicide, and self-harm: Patient distress and system anxiety. Lancet Psychiatry, 2, 275-280.

Sosial- og helsedirektoratet (2008). Nasionale retningslinjer for forebygging av selvmord i psykisk helsevern. (IS-1511/2008). Oslo: Sosial- og helsedirektoratet.

Stangeland, T. (2012). Når sikreste behandling ikke er beste behandling. Tidsskrift for Norsk Psykologforening, 49,. 138-144.

Sykehuset Østfold, (2016). Kvalifiseringsprogram for selvmordsrisikovurderinger - DPS ambulante team og ACT. Dokumentnummer ID: D26585. Elektronisk kvalitetshåndbok.

Sørum, P.E. (2012). Selvmordsforebygging i akutteam ved DPS. - En kvalitativ studie av hvordan hoyskoleutdannet helsepersonell i DPS akutteam beskriver selvmordsforebyggende praksis i temaet etter at de nasionale retningslinjer for forebygging av selvmord i psykisk helsevern ble utgitt. Masteroppgave. Nasjonalt senter for selvmordsforskning og forebygging. Universitetet i Oslo.

Tversky, A. \& Kahneman, D. (1981). The framing of decisions and the psychology of choice. Science, 211, s. 453-458.

Utdannings- og forskningsdepartementet. (2005). Rammeplan og forskrift for videreutdanning i psykisk helsevern.

Walby, F.A. (2017). Resultater; Nasjonalt kartleggingssystem for selvmord i psykisk helsevern og tverrfaglig spesialisert rusbehandling. 9. Nasionale konferanse om selvmordsforskning og forebygging. Oslo 27.-28. november.

Walby, F.A., Odegaard, E. \& Mehlum, L. (2006). Psychiatric comorbidity may not predict suicide during and after hospitalization. A nested case-control study with blinded raters. Journal of Affective Disorders, 92,. 253-260.
Waern, M., Kaiser, N. \& Salander Renberg, E. (2016). Psychiatrists` experiences of suicide assessment. BMC Psychiatry, 16, 440-450.

Walshe, K. \& Shelton, T. (1998). Dealing with clinical risk: Implications of the rise of evidence-based health care. Public Money and Management, 18, $15^{-20}$.

Wand, T., Isobel, S. \& Derrick, K. (2015). Surveying clinician perceptions of risk assessment and management practices in mental health service provision. Australasian Psychiatry, 23, 147-53.

Ostlie, K. (2018). Listening to suicidal patients in psychotherapy: How therapeutic relationships may expand patients' prospects for living their lives. $\mathrm{PhD}$ avhandling. Psykologisk institutt,Universitetet Oslo.

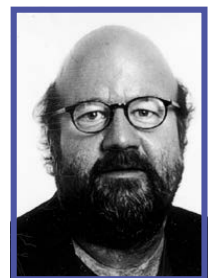

KIM LARSEN er psykologspesialist ved Sykehuset Østfold/RVTS Øst og er også tilknyttet Nasjonalt senter for selvmordsforskning og forebygging, Institutt for klinisk medisin, Universitetet i Oslo. Han er spesialist i klinisk samfunnspsykologi og arbeids- og organisasjonspsykologi. Faglige spesialinteresser er: sosialpsykologi, Freud-biografi og psykoanalysens historie, psykiatrihistorie og suicidologi.

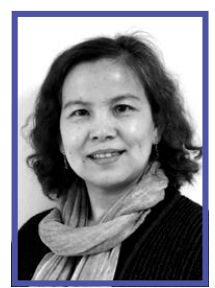

PING QIN er professor, dr. med., spesialist i psykiatrisk epidemiologi ved Nasjonalt senter for selvmordsforskning og -forebygging, Institutt for klinisk medisin, Universitetet i Oslo. Hun er gruppeleder av registerforskning på selvmord og villet egenskade. 